This is the peer reviewed version of the following article: Bolton, S., Laaser, K., and Mcguire, D. (2016) Quality Work and the Moral Economy of European Employment Policy. JCMS: Journal of Common Market Studies, 54: 583-598, which has been published in final form at http://onlinelibrary.wiley.com/doi/10.1111/jcms.12304/abstract. This article may be used for non-commercial purposes in accordance With Wiley Terms and Conditions for selfarchiving. 


\title{
Quality work and the moral economy of European employment policy
}

\begin{abstract}
Following a decade of radical economic and workplace restructuring, it is important to understand how state employment policies support or deny human flourishing. This paper utilises a realist document analysis approach and reviews European employment policy through a moral economy lens. It fuses different moral economy approaches, drawing together Karl Polanyi (1957) and Andrew Sayer (2009; 2011), offering a multi-layered conceptual lens that explores the tensions between a commodification of labour and human needs. A dominant market ideology is revealed, highlighting how quality work has been subsumed by the flexicurity agenda in the EU.
\end{abstract}

\section{Introduction}

At the heart of many philosophical and sociological approaches to defining quality work is an understanding of meaningful and dignified work as a source for human flourishing and well-being, connecting people to each other and the social values and norms of a given society (Bolton, 2007; Breen, 2007; Hodson, 2000; Karlsson, 2004; Sayer, 2009). Arguably, the creation of Europe as a community was based on such a social justice model (Hettne, 1991). The last two decades have witnessed attempts by the European Commission to articulate a model of quality work, evidence of which can be found in the social chapter in the emphasis on the link between opportunities for decent work and social cohesion (EC, 2001). Nevertheless, relatively quickly, the notion of quality work and its various dimensions have been subsumed within developments in European employment policy (EC, 2012).

The objective of this article is to explore the changing meaning of work in the European Commission's approach to employment. It reviews the narrative of the European 
Employment Strategy (ESS) and, specifically, the annual Employment in Europe Reports (EER) from 1998 to 2013. Ideas on moral economy are introduced from influential thinkers, Karl Polanyi (1957) and Andrew Sayer (2007; 2009) and underpin a realist document analysis. Moral economy conceptualises markets as strongly or lightly 'enmeshed in institutions, economic and non-economic' (Polanyi 1957, p. 250), placing people and their capacity to flourish and suffer within the material realities of market society (Sayer, 2000). The paper offers an important contribution in the way it reveals, as an inherent part of the EES, a 'dominant ideology' (Marx and Engels, 2005) fuelling state policies and creating room for exploitative practices and poor work, while narrowing the space for meaningful work and human flourishing. Our argument is that Europe has witnessed a change in a normative understanding of what work and employment policies should offer. Thus, at the heart of the shift of European employment policy towards flexibility, modest social protection and job growth is a radical transformation of the normative framing of work and employment that alters the moral universe of the European Union. It is suggested that both the quantity and quality of work are worthy of close examination, and the paper demonstrates how, with continuing pressures for fiscal austerity and structural reform, the prospect for growth in investment in the creation of 'good jobs' has become undermined in Europe (Heyes, 2013).

The paper explores the analytical framework of moral economy and sets out the methodological approach to document analysis. It then reviews key European Commission communications. By drawing on additional rich and varied sources of secondary data, a nuanced empirical view of the impact of European employment policy through the conceptual lens of moral economy is offered. 


\section{Towards a moral economy}

Moral economy has a rich history of analysing the relationship between people, communities and economic practices in pre-industrial and capitalist societies. Approaches to moral economy can be broadly differentiated according to their interpretation of the social and moral dimensions of economic practices under capitalism (Booth, 1994; Sayer, 2000). The most familiar moral economy accounts are rooted in philosophical, anthropological and sociological approaches to pre-market societies in which 'economic' practices are understood as intermeshed and guided by human needs, customs and mentalities of a 'gemeinschaft' (Toennis, 2001). Here, norms, customs and conventions of kinship and small-scale communities are shaped by peoples' implicit conceptions of the 'good' that governs economic life via notions of mutual reciprocity (Polanyi, 1957; Scott 1976; E.P. Thompson 1991). The strength of these pre-industrial moral economy approaches lie in the portrayal of the economy as serving human needs whilst work is represented as a source for selfactualisation (MacIntyre, 2007; Murphy, 1993; Sayer, 2009). Dominant approaches in the social sciences, however, ranging from Marx (1975) and Weber (1978) to Durkheim (1997), argue that the organising principle of capitalist markets push for a disconnection between the economy and the human and social substance of society through the commodification of labour, land and money.

Karl Polanyi's seminal 'great transformation thesis' (1957) offers an illustration of the 'push' and 'pull' logic between the capitalist class on the one hand. and the state and institutions on the other. Polanyi argues that the political economy is characterised by a 'double movement' between the capitalist class who push for self-regulated markets and the state that aims to shield society and people from the tentacles of self-regulating markets by re-embedding markets in society through social protection and market regulation. Polanyi reveals that sustainable economic practices ought to be embedded in society as labour, land 
and money are 'fictitious commodities' that are vulnerable and cannot be subject to market forces as they rely on exchange mechanisms that belong to the social sphere (Dale, 2010).

There has long been concern expressed that a dominant market ideology imposes a normative acceptance of the market so that community, state and market can barely be differentiated (Marx and Engels, 2005). The strength of the moral economy framework is that it highlights the economic logic of a system that moves beyond individuals, their community and state apparatus (Thompson, 2003). It shows that the market is a form of 'social order'; linking individuals, communities and institutions (Streeck, 2010). The central insight Polanyi offers is that more often than not, the market is (however gently) mediated by institutions, individuals and communities. Of course, how economic and social relations work together differs depending on the contexts that also shape social and institutional structures and establish how employment is organised.

Andrew Sayer's moral economy approach $(2000 ; 2007)$ adds nuance to Polanyi's thesis through his focus on human flourishment. Sayers' thesis is grounded in a NeoAristotelian moral philosophy that characterises people as vulnerable beings, as economically and socially dependent on others, and who have the ability to flourish and suffer depending upon whether their needs are met (Sayer, 2011). Emphasising the human implications of the nature of work and employment under capitalism, Sayer illustrates that labour market participants have 'thick' needs that not only include economic and physical necessities, but also more complex social and psychological needs. Hence the importance of decent work that provides people with sufficient economic means and also offers them recognition and esteem by involvement in meaningful tasks, the ability to create social bonds at work, and opportunities to learn and excel (Breen, 2007; Sayer, 2007). However, Sayer (2009) argues that when employment is driven primarily by short-term economic gain, it limits the availability of meaningful work and opportunities for people to develop their own abilities 
and gain respect and self-esteem; which, in turn, triggers a disconnection between people, communities and organisations (Sayer, 2009).

Combining Karl Polanyi’s and Andrew Sayer's moral economy offers an exploration of how economic practices are intermeshed with, but may also override, moral norms and values. In this spirit, our contention is that from the very early inception of the European Union and, later, the European Employment Strategy, an inherent understanding existed of Europe as a moral economy, with strong support for a dynamic 'double movement' that engaged with the market in creating opportunities for labour mobility and global trade but also tempered its excesses. More recently, this double movement is over-ridden by the dominant ideology of the market so that support for decent work and, by association, a cohesive society is gradually withdrawn. Moral economy is based on a political economy approach to employment studies in its focus on the relationship between market mechanisms, policy making and the changing dynamics of employment conditions but, it in its grounding in moral philosophy, adds a normative dimension that considers the moral and social implications of changes for individuals and society.

\section{Analysis of documents: a realist methodological approach}

European employment policy is a significant factor in supporting the social order of markets; that is, a moral economy. The paper therefore documents the changing narrative of the EES, quality work and flexicurity agendas and situates the analysis within a moral economy framework using a broadly realist approach that acts as a theoretical underlay throughout the review. The term realism is used differently in contexts as widely as art to politics, and to be realist is to assert that entities can exist independently of us, and our understandings of them (Ackroyd and Fleetwood, 2001, p. 6). However, to consider the changing narrative of the European Commission in a realist vein it is vital to question what 
causes it to change, 'to ask what 'makes it happen', what 'produces', 'generates', 'creates' or 'determines' it, or more weakly, what 'enables' or 'leads to it' (Sayer, 1992, p.104).

Concepts like quality work and flexicurity only become interesting from such a perspective when they possess emergent properties, moving objects of analysis beyond aggregates of individual behaviour (Bakewell, 2010). Objects, amongst other things, can be organisations, people, relationships, attitudes and resources; they form the basic theoretical building blocks for realist explanation (Easton, 2010, p.120). The object guiding the review is a moral economy of employment policy, with a special focus on themes of quality work and flexicurity. Among a wealth of different employment publications from the EC, the decision was made to focus on different iterations of the European Employment Strategy (EES), with a detailed perspective on employment as a 'matter of common concern' $(\mathrm{EC}, 1997)$ gained from examination of the annual European Employment Report (EER) from 1998 (the year following the Amsterdam Treaty which launched the ES). Other Commission documents, particularly those focused on the development of a quality work framework for Europe, are also drawn upon.

Documents are open to manipulation, but they act as important receptacles forming the basis of resources for action and mobilization as they have 'effects' (Prior, 2004, p.91). In this case, a visible effect of our analysis of European Commission documents is the argument and realisation that the balancing of flexibility and security - once felt to be essential - has weakened throughout time. A co-existing effect is the foregrounding of more jobs against a diminishing prevalence on better jobs and attempts to define quality work. Indeed, communications regarding orchestrated efforts to carefully define and promote quality work are elusive and difficult to trace. Following a review of the documentation we draw together key effects, creating a review of prominent themes; including, quality work, (in)security, individual (rather than collective) action, exclusion, and employment rates. The paper then 
situates the changing narrative within a moral economy frame, drawing on additional secondary data sources to highlight the impact of these effects upon people's capacity to flourish.

\section{Quality work and European Employment policy - a review}

Concerns regarding the creation of opportunities for decent work are central to the European Commissions' aims. They are expressed in the social chapter of the Maastricht Treaty (EC, 1992) and more recently in the Amsterdam Treaty (EC, 1997c), as attempt are made to universalise across the European Union rights to collective voice, fair pay, opportunities for learning and development, equal opportunities and protection for vulnerable workers. Hence the social chapter represents the original core values of a social justice model which views full employment and quality work as a basis for a successful and progressive European Community (EC, 1997c). Thus, the notion of 'more and better jobs' rests at the heart of EC employment policy, though, as the following review suggests, both the career and the concept of quality work has been a chequered one.

Early EERs talk of employment in terms of 'high road, high skill, high trust, high quality' (EC, 1998: 8). Between 1998 and 2001 there is an air of optimism throughout the reports concerning employment growth with job quality as a key focus. The 'four pillars' of the employment strategy (EC, 1998), 'employability, entrepreneurship, adaptability and equal opportunities' are viewed as key drivers with a particular emphasis on social partnership and collective endeavour as the route to the successful enactment of strategic goals (EC, 1998). From 1999, however, job quality is placed under particular scrutiny, though at that time there is little attempt to carefully define what a good job may look like (EC, 1999). 'More and Better' jobs enters the narrative for the first time $(\mathrm{EC}, 1999)$ and is endorsed in the Lisbon Strategy (EC, 2000). Yet during the same period, concern is expressed about the spectre of 
underemployment through the growth in insecure work, and the EERs hold warnings of tiered labour markets as substantial gender gaps and regional differences remain part of the employment growth picture (EC, 2000, 2001). The same period witnesses the initiation of the flexibility versus security debates that will continue for some time to come (EC, 2000), though the spotlight on the need for institutions to be flexible, rather than individuals, remains strong (EC, 1999, 2000, 2001a).

In this setting, as part of a growing optimism that the Lisbon Strategy employment target of $70 \%$ can be reached, quality work is a significant feature of EC communications in 2001 (EC, 2001a, b), when a special European task force set out to create a means of statistically defining and measuring quality work. What has become known as the 'Laeken framework' defines the quality of work along two central axes: characteristics of jobs and work and wider labour market context (EC, 2001b:10), which addresses the Social Policy Agenda 'triangle'; linking broad economic, employment and social policies that will lead to social cohesion (EC, 2001). This phase reveals a growing divergence in narrative between concern for the third of employed people who are in low quality jobs (EC, 2000, 2001) where security is a key component of job quality, while simultaneously offering statements like greater labour market flexibility is required where concerns regarding 'bad jobs spreading in Europe can be dispelled' (EC, 2001: 10). The competing discourse is demonstrated by the Employment in Europe report (2000) expressing concern over the instability of jobs and associated insecurities on one hand, but articulating on the other hand that, 'the majority of people working part-time and in temporary jobs do so out of choice' (p 29).

The contradictory threads of narrative around security, flexibility and job quality remain a feature of the 2002 Employment in Europe Report, though in the context of a slowing of growth in employment and new concerns regarding increasing workplace 'stress and alienation' (EC, 2001). Nevertheless, commitment to quality work remains strong 
demonstrated by the claim that 'quality work is not a fair weather policy' (EC, 2002: 106). Hence there is clear message for EU policy makers: that 'job quality can improve employment persistence and job creation and reduce risk of job loss, unemployment, or social exclusion' (pg 98). However, there is also new emphasis placed on 'low quality work as a transition to better quality work' (pg 12) with the report arguing for the value of promoting transitions into jobs of higher quality, through training, with the aim of strengthening integration into the labour market.

The new EES introduced in 2003 has three objectives: full employment, quality and productivity at work, social cohesion and inclusion (EC, 2003: 10). While sharing similarities with its predecessor, the 1998 EES, there are differences in emphasis. For example, quality work is directly associated with productivity and in discussion of 'adaptability' there is a stronger emphasis on the adaptability of individuals as opposed to institutions (EC 2004, 2005, 2006). During this phase the effects of economic slowdown become apparent and in the 2005 EER, Europe is described as being 'mired in economic difficulty' (EC 2005: 4). There is also a consistent expression of concern regarding a two tier labour market, some disappointment in the low transition rates for people moving from poor to better quality work, and continued effort to promote flexibility while also calling for effective social support mechanisms (EC, 2002, 2003, 2004, 2005). Despite only the Nordic countries reporting any major success in people transitioning from poor quality work to 'better jobs', the narrative around part-time and fixed-term contracts emerges as a positive inclusion mechanism (EC, 2004). This is couched by being beneficial to companies rather than the previous focus on insecurity of employment (EC, 2005: 104).

The EES is reviewed in 2005 and the Lisbon strategy re-launched with a stronger emphasis on 'jobs and growth' (EC, 2005a). As ambitions to reach Lisbon employment targets become 'increasingly challenging', rising numbers of part-time and fixed-term 
contracts are positively reported as a 'notable development' (EC, 2006: 21), and there are calls to ease 'stringent employment protection' (pg 103) in order to support flexible labour markets. During this period the narrative around quality work changes significantly. In the 2004 and 2005 EER quality work is mentioned in terms of feeding into increased productivity, and in the 2006 and 2007 reports it is barely mentioned, failing to appear as a distinctive feature. The 2007 report, in particular, demonstrates a change in tone: it articulates how quality workplaces are integral to the flexicurity strategy (pg 125), but only deals with a few specific themes like upskilling and part-time and fixed-term jobs, failing in large to deal with the quality of jobs.

Communication in 2007 is dominated by the introduction of the "common principles of flexicurity' (EC, 2007b). The European Commission defines flexicurity as 'an integrated strategy to enhance flexibility and security in the labour market' (EC, 2007b). Modelling European employment relationships after Danish and Dutch labour market models, flexicurity represents an attempt to heighten external employment flexibility by loosening employment protection laws while establishing active labour market policies that offer adequate unemployment benefits in-between jobs (EC, 2006, 2007). An emergent feature during this period is the emphasis on 'quality workplaces' (EC, 2007: 125), with High Performance Workplaces (HPWPs) appearing to overtake quality work as a key focus. Nevertheless, there is some critical reflection as empirical data illustrates 'evidence of HPWP showing mixed results' as reports of work intensification rise (EC, 2007: 145).

The 2008 EER contains the first full feature on quality work since 2003 in its statement that 'flexicurity needs to be seen in the broader and complimentary context of job quality' (EC, 2008: 19). The report confesses that 'no clear cut conclusions can be drawn regarding job quality developments' (pg 147), and suggests that the focus on quality work has 'waned in recent years' (pg 147). A new 'enriched framework of job quality' is proposed and 
'good jobs' are once again identified as a key element of a renewed European social model (pg 148). This proposal reflects repeated efforts to attempt to define quality work and continued difficulties due to the lack of any 'standard or agreed definition of quality in work in the academic and expert literature' (EC, 2001b:7; 2002; 2003; 2007d). However, despite the previous commitment to reinvigorating the search for a model of quality work it once again disappears from view in subsequent EERs.

By 2009 and 2010 the focus of the reports is the impact of the crisis and growing numbers of unemployed. The EC places an emphasis on short-term action stating that 'workers and companies must be given the necessary means to successfully adjust to these changing realities' (EC, 2009: 25). From these discussions, it is clear flexicurity remains at the heart of Europe 2020 (EC 2010a). There is little doubt that the onus is on the individual to become more flexible; or to be 'given the tools to adjust' (EC, 2010) in the face of restricted employment opportunities and increased business freedom. This divergence is supported by statements like, 'people made redundant by their employer may see it as an opportunity to set up their own business' (EC, 2009: 40), for example. Moreover, short-time temporary work arrangements (STWAs) are proposed as a means to stem the 'flow of job closures' (pg 41), allowing companies to reduce working hours and/ or wages below contractual agreements. This is perhaps unsurprising given the context, whereby temporary and fixed-term contracts are also a feature in offering 'multiple opportunities' to employers (rather than employees).

Moving forward, the 2010 EER offers a pessimistic view as the economic crisis intensifies; neither does it focus on quality of work (EC, 2010). Nevertheless, a new attempt to define quality work is made by the UNECE taskforce in 2010 (EC, 2010b). It suggests simplifying the original Laeken framework from two dimensions and ten criteria into seven dimensions, one of which contains a new focus on income. However, the 2010 report removes the term framework to 'avoid any possible implication for defining quality of 
employment' and the discussion centres on 'potential indicators for measurement of quality of employment' and new indicators are 'primarily designed to measure quality of employment from the perspective of the individual or worker' (EC, 2010b: iii). This indicates a shift in how quality of work is related to socio-economic policies and trends and a wider distancing from the more holistic concept of 'decent work'. There are also fewer normative statements concerning aspirations for quality employment and a sharpened focus on how to provide accurate measurement. In the early reports, there is an emphasis on inspirational narratives and visions for a social Europe. In the 2007 report, however, the tone is one of modernisation and adjusting to new difficult realities. Nevertheless, the report makes a special effort at criticising the entrapment of workers in temporary work - important because the discussion highlights the flaws in overarching policy strategy that fosters employment growth primarily through the development of temporary and atypical employment.

Importantly, the newly invigorated focus on quality work appears to go unnoticed in subsequent Employment and Social Developments (ESD) reports (that from 2011 replace the EER report). Though job quality is listed as part of a long-term strategy for social inclusion and the fight against poverty, it is not a defined feature and by 2013 is not mentioned at all. Rather, there is a growing significance given to health and safety at work as a key measure of job quality that grows in emphasis through to the 2013 ESD. The linking of the former employment report with a report that includes social developments brings a new emphasis in the reports from 2011, 2012, and 2013 on the social outcomes of weaker labour market performance. This is significant because there is growing concern for 'in work poverty' (EC, 2011); people trapped in temporary contracts (EC, 2011 and 2012); underemployment (EC, 2011 and 2013); the gender pay gap (EC, 2012); and the divergence in life chances between people in northern and southern European countries (EC, 2012). A 2012 report found that $14 \%$ of jobs in Europe were high pay, good jobs; $37 \%$ were well-balanced good jobs; $29 \%$ 
were poorly balanced jobs, leaving $20 \%$ of jobs that were of poor quality (Eurofound, 2012). Nonetheless, a defensive stance remains as temporary contracts are claimed as a major 'adjustment variable' for companies during the economic crisis. Importantly, there is also a continued call for increased labour market deregulation and the suggested active labour market polices' focus on entrants into the labour market rather than either the welfare of the unemployed or the quality of the proposed work (EC, 2012). Overall, the demise of pressure for collective action by the state, business or social partners and the growing emphasis on individuals to weather the storm of unemployment or precarious work becomes more apparent in the recent 2011, 2012 and 2013 reports. However, there is some reflection on the European Employment Strategy as a failed project in the statement that 'the EU does not fulfil its fundamental objective to benefit all members states' (EC, 2013: 23).

\section{European employment policy through the lens of a moral economy}

The realisation of a standard for quality work can be understood as a collective achievement rather than an individual attribute of different types of jobs or individual workplaces. Indeed, the precarious relationship between economic considerations, intensified market and profit competition, social and moral norms, and the visible and invisible double movements they generate, are inherent in the history of employment policies and enshrined in international constitutions (Standing, 2009). For instance, while establishing the International Labour Organisation (ILO), Albert Thomas stressed in a Polanyian tone that, '(t)he social factor must take precedence over the economic factor; it must regulate and guide it in the highest cause of justice' (Thomas, 1931:12). In this sense, the ILO is a crucial agent in maintaining a double movement that challenges market mechanisms to establish dignified work as a basic human right (ILO, 2005: 10; 2013). 
A moral economy lens suggests recent developments in European employment policy rely primarily on economic arguments rather than on those built on a social justice model (Block, 1990); acting against a quality of life approach that relies on social as well as economic indicators (Burchell, et al, 2014).

As this article argues, periods in which markets dominate the social sphere are not the result of a disembeddness of markets. Rather, markets are always embedded, but in different ways, during different eras. For example, in times of economic austerity a market approach establishes a 'light' form of employment regulation, perhaps because previously established counter-movements that aimed to protect the social are either not strong enough or do not function as they used to (Dale, 2010). Hence why the dominance of flexicurity in European employment policy can be understood as a result of the changing position of the state and supranational policy making institutions. Though these institutions are, for Polanyi, pivotal agents in constraining the market, the last two decades provide ample evidence that the state and supranational institutions play a crucial role in deregulating markets and decreasing social welfare provision (Crouch and Keune, 2012; Standing, 2009). As this process unfolds during the review of 14 years of the European Employment reports, labour has become increasingly objectified, individualised, quantified and couched in terms of maximising behaviour and efficiency (Keune and Serrano, 2014; Petijean, 2012; Pochet et al., 2009).

This is explicated in temporary or distanced contractual relationships as proposed by the policy on flexicurity and labour market transition. As the above review of European employment policy suggests, there has been a shift of focus in the EU from job quality to job creation, with the emphasis on labour market reforms aiming to make them more efficient and adaptable to change. Concerns about excessive labour market rigidity, which is detrimental to employment creation, has led a number of Member States to undertake, since the late 1990s, reforms aimed at tackling employment protection rules. In most cases, the 
reforms contribute to an underscoring of the inherent inequalities of a core/ periphery model in the way they substantially lessen regulation on the use of temporary and other nonstandard jobs, while maintaining existing provisions on permanent employment contracts (Bosch et al, 2007; Schmidt, 2014). Initially contributing to significant reductions in unemployment, this could not be maintained as austerity measures in the context of the financial crisis bite hard into job creation initiatives at both state and employer level (Hyman, 2011). At the same time, the failure to unravel the continued reliance on a core/ periphery model has led to segmented labour markets with increasing numbers of workers 'trapped' in temporary contracts with little chance of moving to more secure jobs or gaining access to training (Heyes and Lewis, 2013), shifting 'risks to individuals or small enterprises without, yet, persuasive compensations of security (...)' (Schmidt, 2014:109). Thus resulting in a widespread perception of higher job insecurity and precariousness (Boeri, 2008; Standing, 2011) for 'outsiders', most especially low-skilled workers in contingent jobs (Vliet and Nijoer, 2012). High educational attainment and/ or long-term employment arrangements also no longer constitute a guarantee of income security, meaningful work and career progression, as work intensification and wage inequality has significantly increased among highly educated and older workers, together with a rising incidence of long-term unemployment (Pochet et al., 2009).

Under the Flexicurity rubric, the idea that work has become riskier and unstable has become normalised and the 'risk shift' (Hacker, 2006) from employer and state to individual is accepted as a necessary move towards a more dynamic labour market. As a result, employees' face higher risks and may be forced to accept substantial wage cuts and/ or deteriorating working conditions in order that gaps between employment are not prolonged. There is, likewise, evidence to suggest that worker autonomy is decreasing (Green, 2006; Burchell, 2009); opportunities for training and development are diminished (Erhel and 
Guergoat-Larivière, 2010); mental health at work is deteriorating (EUROFOUND, 2010a); and Trade Unions, once seen as a pillar of the social charter, side lined (Hyman, 2011; Pochet et al., 2009). This conveys the idea that having more jobs implies that many of them are of 'bad' quality. Indeed, though knowledge intensive, higher quality jobs have been created, there is a widening gap between high and low road labour markets (Andor, 2011; EUROFOUND, 2013) and the number of 'working poor' is on the rise (EUROFOUND, 2010b). Overall, the emphasis on quality work has waned (EUROFOUND, 2012), defying the notion that a singular emphasis of 'more jobs' is the path to a vibrant European community.

These developments are taxing to policy-makers who rely on the balance between employer and state support to make the flexicurity concept work (EC, 2009, 2010, 2011). Indeed, flexicurity strategies should produce superior outcomes for both employers and workers (Burroni and Keune, 2011: 48). However, to rely on employers' enlightened selfinterest to provide decent work could always have been described as naïve. As observers of a 'machinery of social injustice' observe, if there have been improvements in living and working conditions in Europe it is not because of philanthropy but because of state intervention (Barry, 2005: 25; Polanyi, 1957); often expedited at the level of member states with strong social partner networks and in contradiction to the European Commission's liberal bias (Klindt, 2011; Wagner and Lillie, 2014).

Hence, we see the dynamic nature of a market system rooted in a moral economy as institutions such as trade unions and NGOs, jostle with private enterprise and the state to mediate the excesses of an often exploitative system where incremental improvements are introduced (i.e. new protective legislation for older workers, attempts to equalise employment rights across standard and non-standard work arrangements, and the promotion of gender equality). Nevertheless, flexicurity represents a systemic failure to address the need for 'more 
and better jobs'. It assumes a rational model of utility seeking humanity based on a system that relies on equal investment, and trust that both employers and state will keep their side of the bargain between allowing an increase in job insecurity without undermining the income security of individuals (Dewan and Peek, 2007; Erhel and Guergoat-Larivière, 2010). Europe 2020 and its central pillar, flexicurity, is not without its critics, including EUROFOUND's 2012 research report that highlights the potential human and broader social costs of an overemphasis on individual flexibility in the flexicurity narrative of the EC (EUROFOUND, 2012).

From a moral economy perspective, flexicurity neglects the importance of work as an end in itself and is based upon an instrumental understanding of work as a means to an end (Sayer, 2009). Indeed, flexicurity represents a novel, more sophisticated form of commodifying labour, rendering people as objects to be moved as the market demands, without the corresponding mechanisms that support people's capacity to deploy their capabilities in a meaningful way (Orton, 2011). Here, a thin and market driven distributive logic shines through as policies push for an increasing inclusion of people in the labour market and place them in flexible, and thus, contingent jobs without being concerned about the content, security and quality of jobs (Booth, 1994; Polanyi, 1957). In its reliance on people's endeavours to remain employable, flexicurity places all the emphasis on the individual to adapt in a continual process of upskilling, with the assumption that moving from job-to-job, workplace-to-workplace, and community-to-community, is acceptable to the human condition. Meanwhile, there is no recognition of how insecurity renders people vulnerable beings and disembeds them from a community of workers and work as a source of flourishment (Fineman, 2004; Sayer, 2009). Nor are there acknowledgements that successful employment relies on an 'ethical surplus' (Sayer, 2007) created through the formation of bonds and mutual obligations. Indeed, it has long been recognised that distance and 
anonymity destroy human connections that are featured in the web of commitments and obligations that make up the moral economy and that economic relations rely upon (Bolton, et al, 2012; Sennett, 1998). In effect, the destruction of the 'thick', and the dominance of a 'thin' and conditional, employment relationship model is not only damaging to a moral economy but also to a market one. Little wonder that flexicurity is described as a 'moral hazard' (Bingley et al, 2012) underpinned by the EU's social deficit. We argue here that, within this system, people become fictitious commodities in a manner that even Polanyi could not have imagined. For many, this represents a 'distressing fatalism' about the implications of precarious, poor, and no work at all (Hyman, 2011: 9).

While there are various interpretations about the current employment situation across European labour markets, further consideration needs to be given to the unemployed and underemployed. In what has been described as a 'transformational crisis' the structure of unemployment is changing, with the young and low-skilled being affected the most (Andor, 2011; EUROSTAT, 2014). For the 'lost generation' of the millions of young people currently unemployed across Europe (Bell and Blanchflower, 2010), even a bad job appears unlikely to come their way. Moreover, what about those people who are often not afforded the benefits of citizenship (Longhi, 2013) fighting for survival outside of formal employment and in precarious arrangements? Though flexicurity is meant to create movement in the labour market so that more people are given opportunities for employment, its orientation is based on principles of a meritocracy that arguably fails to recognise the structured nature of the low-skills cycle for those at the bottom of the social spectrum (Barry, 2005). Once again, the foundation of a moral economy is undermined as people lose their rightful space, place and status in work and social communities, so that the notion of a European Community becomes 'a landscape without figures' (Charlesworth, 2004). 


\section{The embeddedness of European employment policies}

Our argument is that Europe is currently witnessing a paradigm shift in a normative understanding of what work and employment policies should offer, which is underpinned by the emergence of a dominant ideology that fuels state policies and creates room for the ready acceptance of exploitative practices and poor work. There are several important parts to this picture, but notably, European economic policy exacerbates inequalities of opportunity for decent work across European states while profit considerations are prioritised over social and human matters; i.e., the dismantling of social protection (Barnard, 2014). Recent changes in the emphasis of the European Employment Strategy also reflect developments in the neoliberal agenda of advanced economies that establish a division of labour endorsing labour market participants as rational actors and as means to an end (Sayer, 2009).

Looking through the lens of moral economy offers the opportunity to see beyond this dominant ideology and to ask 'to what ultimate end?' European social and employment policies are characterised by a dilemma that rests on two conflicting paradigms. While the Social Policy Agenda of Europe rhetorically endorses a view of people as ends in themselves (Somavia, 2004), a series of European 'strategies' culminating in the EURO 2020 (EC, 2010a) emphasise the need for flexibility, adaptability and competitiveness above security, autonomy and well-being. From a policy perspective, what is critical is whether the economic and social investment roles are in balance. In practice, more flexibility is demanded of workers, but little security is offered in return. Though flexicurity was advanced at EU level as a more balanced approach than purely deregulatory (Viebrock and Clasen, 2009), for many the political subtext is that it is a 'Trojan horse for neo-liberal policies' (Begg et al., 2010) representing an advanced disembedding processes (Hyman, 2011).

In contrast, a moral economy approach suggests that the European Union has undergone fundamental changes as it grows and develops into a 'community'. Nevertheless, 
whatever shape its economic policies take, Europe has always been and remains (though in different shapes and forms) moral; that is, embedded in the non-economic realm of webs of norms and values of humanity (Booth, 1994; Sayer, 2000). This moral embeddedness is reflected in responses to the Employment Strategy where a range of critical voices - member states, trade unions, academic commentary (Salais, 2014; Schmid, 2014) and the European Commission itself - express concern that the social justice dimension is being sacrificed to the economic (EC, 2007: 9/19; 2012; Pochet, 2010); highlighting an ongoing 'double movement' (Polanyi, 1957) where policies fuelled by neo-liberalism create the need for state and institutional support. Most especially, concern is expressed about the concept of flexicurity creating flexibility without the necessary security safety nets being in place and that the development of more jobs does not necessarily imply better jobs (EC, 2007: 44/ 63; 2013). Indeed, some believe social policy has always been the poor relation to the EU's economic dimension (Bernard, 2014: 204).

There is little doubt that the logic of accumulation in a market society distorts the moral economy and undermines its possibilities, but recent European commission narrative around the detrimental consequences of flexible labour market policies reveals how this logic is already controlled in some ways through state legislation and human values. In other words, there are countervailing tendencies that may not halt the logic of accumulation but do serve to brake and disrupt it (Sayer, 2005). After all, capitalism relies upon non-market institutions - such as the family and gendered divisions of labour, as well as prevailing economic organisation. Our analysis suggests that the global love affair with market mechanisms remains substantially, but not entirely, unchallenged. It reveals that the community dimension of the European Union adds a normative understanding and expectation across Europe that the market will not be left unfettered by moral constraint. What this highlights are tensions and contradictions as the logic of capitalism pulls in one 
direction and the values and norms of a moral economy pull in another. What appears the right thing to do may be, and often is, compromised by the need to rationalise and maximise output to match the demands of a competitive market. Hence, within an analysis of the moral economy, the management of European Employment Policy is complex and will present many dilemmas. A central dilemma rests with the questions of whether job creation combined with job quality, a policy of full employment and fulfilling jobs (Spencer, 2012), is simply too much to ask for and it becomes accepted that any job (good or bad) is better than no job at all. After all, without paid employment there is little prospect for decent work and a decent life. This dilemma is infused with a moral character, not just an economic one as economy and society are densely intertwined (Streeck, 2010).

What the moral economists give us is a powerful way of thinking about European Commission policies, their institutional and normative dimensions and the relationships that are created, supported or destroyed within them (Booth, 1994: 664; Streeck, 2010). As moral economists suggest, the European community is not only made up of different political regimes, employment systems and institutional structures (a political economy) but also a range of moral universes that work to resist, change and mediate how policy is imposed and enacted.

\section{References}

Ackroyd, S, Fleetwood, S (2001) Realist perspectives on management and organisations: Psychology Press.

Albert, T (1931) 'Preface' to ILO, The International Labour Organization: The First Decade, London: George Allen and Unwin for the ILO, pp. 5-12.

Andor, L (2011) 'Evaluating flexicurity in the economic, employment and social crisis', Speech to High-level conference on Flexicurity, Brussels, $14^{\text {th }}$ November 2011, 
availablefrom:http://europa.eu/rapid/pressReleasesAction.do?reference=SPEECH/11/ 751\&format $=$ HTML\&aged $=0 \&$ language $=E N \&$ guiLanguage $=e n$.

Barnard, C (2014) EU Employment Law and the European Social Model: The past, the Present and the Future, Current Legal Problems, 67, 199-273.

Barry, B (2005) Why Social Justice Matters, Cambridge, Polity Press.

Bakewell, O (2010) Some reflections on structure and agency in migration theory, Journal of Ethnic and Migration Studies, 36(10), 1689-1708.

Begg, I, Ehrel, C and Mortensen, J (2010) 'Medium term employment challenges', European Commission, Brussels 2010.

Bell, D, Blanchflower, D (2010) 'Young People and Recession: A Lost Generation?' FiftySecond Panel Meeting on Economic Policy, Einaudi Institute for Economics and Finance.

Bingley, P, Cappellari, L and Westergård-Nielsen, N (2012) 'Flexicurity, wage dynamics and inequality over the life-cycle', Italian Ministry of Economics and Finance, Working paper series, March 2012.

http://www.dt.tesoro.it/export/sites/sitodt/modules/documenti_en/analisi_progammazi one/working_papers/WP_N_13.pdf.

Block, L (1990) Postindustrial Possibilities: A Critique of Economic Discourse, Berkeley, CA: University of California Press.

Boeri, T, Conde-Ruiz, I and Galasso, J (2012) 'The Political Economy of Flexicurity', Journal of European Economics Association, 10, 4, pp. 684-715.

Bolton, SC (2007) Dignity in and at Work: Why it Matters, Dimensions of Dignity at Work. Bolton, SC, Oxford, Butterworth-Heinemann.

Bolton SC, Houlihan, M and Laaser, K (2013) Contingent work and its contradictions: towards a moral economy framework. International Journal of Business Ethics 
111(1): 121-32.

Bolton, SC, Laaser, K (2013) Work, employment and society through the lens of a moral economy, Work, Employment and Society, 27(3): 508-525.

Booth, WJ (1994) 'On the Idea of the Moral Economy', The American Political Science Review, 88(3): 653-667.

Bosch, G, Rubery, J and Lehndorff, S (2007) 'European employment models under pressure to change', International Labour Review, 146 (3-4).

Burchell, B (2009) 'Flexicurity as a moderator of the relationship between job insecurity an psychological well-being'. Cambridge Journal of Regions, Economy and Society, 2 (3): $365-378$.

Burchell, B, Sehnbruch, K, Piasna, A, \& Agloni, N (2014) 'The Quality of Employment in the Academic Literature: Definitions, Methodology and Ongoing Debates', Cambridge Journal of Economics, 38: 459-477

Burroni, L, Keune, M (2011) Flexicurity: A conceptual critique, European Journal of Industrial Relations, 17(1), 75-91.

Breen, K (2007) 'Work and emancipatory practice: towards a recovery of humanbeings' productive capacities. Res Publica: 13(4): 381-414.

Charlesworth, S (2004) A Phenomenology of Working Class Experience, Cambridge: Cambridge University Press.

Crouch, C (2011) The Strange Non-death of Neo-liberalism, New York:Wiley.

Crouch, C. M. Keune (2012). 'The Governance of Economic Uncertainty: Beyond the 'New Social Risks' Analysis.' In: Bonoli, G. and D. Natali (Eds.) The Politics of the New Welfare States in Western Europe, pp. 55-67. Oxford: Oxford University Press, 2012 Dale, G (2010) Karl Polanyi: The limits of the market. Cambridge: Polity. 
Dewan, S, Peek, P (2007) 'Beyond the Employment/Unemployment Dichotomy: Measuring the Quality of Employment in Low Income Countries', Policy Integration and Statistics Department International Labour Office Geneva, available from: http://www.ilo.org/wcmsp5/groups/public/@dgreports/@integration/documents/publi cation/wcms_091732.pdf.

Durkheim, E (1997) The Division of Labor in Society: Free Press.

Easton, G (2010) Critical realism in case study research. Industrial Marketing Management, 39(1), 118-128.

Erhel, C, Guergoat-Larivière, M (2010) 'Job quality and labour market Performance', CEPS (Centre for European Policy Studies) Working Document, available from: 330/June2010,http://aei.pitt.edu/14580/1/No_330_Ehrel_and_Guergoat_on_Job_quali ty_revised_final.pdf.

EC (European Commission) (1998 to 2010 inclusive) Employment in Europe Report, available from: http://europa.eu/eiro.

EC (2011to 2013 inclusive) Employment and Social Developments, available from: http://europa.eu/eiro.

EC (2001b) Employment and Social Policies: A Framework for investing in Quality, available from: ec.europa.eu.

EC (2005) Council Decision on Guidelines for the Employment Policies of the Member States, Official Journal of the European Union, Council of the European Union, available from: www.eur-lex.europa.eu.

EC (2007a) The Treaty of Amsterdam, available from: www. europa.eu.int.

EC (2007b) Commission Communication on Flexicurity, Brussels $17^{\text {th }}$ June, 2007, available from:http://europa.eu/rapid/pressReleasesAction.do?reference=MEMO/07/256\&form at $=$ HTML\&aged $=0 \&$ language $=E N \&$ guiLanguage $=$ en. 
EC (2007c) Towards common principles of flexicurity, available from: http://register.consilium.europa.eu/pdf/en/07/st15/st15497.en07.pdf.

EC (2007d) Report of the Fourth Seminar on the Measurement of the Quality of Work, June 2007, available from: www.unece.org.

EC (2010a) An Agenda for New Skills and Job, Strasbourg 2010, available from: http://eurlex.europa.eu/LexUriServ/LexUriServ.do?uri=COM:2010:0682:FIN:EN:PDF.

EC (2010b) Measuring quality of employment: Country pilot reports, Economic Commission for Europe, prepared by UNECE Taskforce, Geneva.

EC (2012a) Terms of Reference for the Expert Group on Measuring Quality of Employment, January 2012, available from: www.unece.org.

EC (2012b) Europe 2020 - Europe's Growth Strategy, available from: http://ec.europa.eu/europe2020/index_en.htm.

EUROSTAT (2014) Euro Area Unemployment - Press Release September 2014, available from: estat-monthly-unemployment@ec.europa.eu.

EUROFOUND (2002) 'Quality of Work in Europe: Issues and Challenges', Foundation Paper, Office for Official Publications of the European Foundation for the Improvement of Living and Working Conditions, Dublin, Ireland.

EUROFOUND (2008) (European Foundation for the Improvement of Living and Working Conditions) 'Employment in Europe Report', Office for Official Publications of the European Foundation for the Improvement of Living and Working Conditions, Dublin, Ireland.

EUROFOUND (2010a) 'Work Related Stress', Office for Official Publications of the European Foundation for the Improvement of Living and Working Conditions, Dublin, Ireland.

EUROFOUND (2010b) 'Working Poor in Europe', Office for Official Publications of the 
European Foundation for the Improvement of Living and Working Conditions, Dublin, Ireland.

EUROFOUND (2012) 'The second phase of flexicurity', Office for Official Publications of the European Foundation for the Improvement of Living and Working Conditions, Dublin, Ireland.

EUROFOUND (2012) 'Trends in job quality in Europe', A report based on the fifth European Working Conditions Survey, Publications office of the European Union, Luxembourg.

EUROFOUND (2013) 'Living and Working in Europe', Office for Official Publications of the European Foundation for the Improvement of Living and Working Conditions, Dublin, Ireland.

Fineman, M (2004) The autonomy of myth: A theory of dependency. New York, The New Press.

Graeber, D (2011) Debt: The First 5,000 Years, New York, Melville House.

Green, F (2006) Demanding work - the paradox of job quality in the affluent economy, Princeton University Press.

Hacker, J (2006) The great risk shift: the new economic insecurity and the decline of the American dream, Oxford, Oxford University Press.

Harvey, D (2010) The Enigma of Capital and the Crises of Capitalism, London: Profile Books.

Heyes, J (2013) Flexicurity in crisis: European labour market policies in a time of austerity, European Journal of Industrial Relations, 19(1): 71-86.

Heyes, J, Lewis PC (2013) Employment protection under fire: Labour market deregulation and employment in the European Union, Economic and Industrial Democracy. Published online 25 July 2013as doi: 10.1177/0143831X13491842. 
Hettne, B (1991) "Europe and the Crisis: The Regionalist Scenario Revisited," In Marguerite Mendel and Daniel Sale e (eds.), The Legacy of Karl Polanyi.

Hyman, R (2011) ‘Trade Unions, Lisbon and EUROPE2020: from dream to nightmare', LSE discussion paper, available from: http://www2.lse.ac.uk/europeanInstitute/LEQS/LEQSPaper45.pdf

ILO (2005) Decent Work: The Heart of Social Progress, available from: http://www.ilo.org/public/english/decent.htm.

ILO (2013) World of Work Report: Repairing the Economic and Social Fabric: International Labour Organisation, Geneva, International Institute for Labour Studies.

Karlsson, J (2004) 'The ontology of work: Social relations and doing in the sphere of necessity'. In: Fleetwood, S. and Ackroyd, S.: Critical realist applications in organisation and management studies, pp.84-104. London: Routledge.

Keune, M., A. Serrano (2014) 'The power to name and struggles over meaning. The concept of flexicurity. In: Keune, M. and A. Serrano (eds.): Deconstructing flexicurity and developing alternative approache, pp. 1-26. Taylor and Francis.

Lie, J (1991) Embedding Polanyi's Market Society, Sociological Perspectives, 34(2): 219235.

MacIntyre, AC (2007) After virtue: a study in moral theory, University of Notre Dame Press. Marx, K (1975) Economic and philosophical manuscripts of 1844, Early writings. L. Colletti. Harmondsworth, Penguin.

Marx, K, Engels, F (2005) The Communist Manifesto: A Road Map to History's Most Important Political Document, Haymarket Books.

Murphy, JB (1993) The Moral Economy of Labor: Aristotelian Themes in Economic Theory, Yale University Press.

Orton, M (2011) 'Flourishing lives: the capabilities approach as a framework for new 
thinking about employment, work and welfare in the $21^{\text {st }}$ century', Work, Employment and Society, 25 (2): 352-360.

Pochet, P, Boulin J and Dufour, C (2009) 'Lisbon: a failed strategy or still relevant for the future', Transfer, Vol. 15, No. 1, 2009, pp. 21-31.

Pochet, P (2010) 'What's wrong with EU2020?', ETUI briefing paper, Issue 2/ 2010.

Polanyi, K (1957) The Great Transformation, New York: Rhinehart.

Rubery, J (2011) 'Reconstruction amid deconstruction: or why we need more of the social in European social models', Work, Employment and Society, 25, 4: 658-674.

Salais, R (2014) Labour, Capabilities, and Situated Democracy. In: Keune, M. and A. Serrano (eds.): Deconstructing flexicurity and developing alternative approaches, pp. 116-134. Taylor and Francis.

Sayer, A (1992) Method in social science: A realist approach. Psychology Press.

Sayer, A (2000) ‘Moral economy and Political Economy’, Studies in Political Economy, Spring: 79-103.

Sayer, A (2005) The Moral Significance of Class. Cambridge: Cambridge University Press. Sayer, A (2007) 'Moral Economy and Employment' in S.C. Bolton, and M. Houlihan, (eds.), Searching For The Human In Human Resource Management: Theory, Practice, And Workplace Contexts. London: Palgrave.

Sayer, A (2009) Contributive Justice and Meaningful Work. Res Publica 15(1): 1-16.

Sayer, A (2012) Capabilities, Contributive Injustice and Unequal Divisions of Labour. Journal of Human Development and Capabilities, 13(4): 580-596.

Schmid, G. (2014) Beyond Flexibility. Active Securities for flexible employment relationships. In: Keune, M. and A. Serrano (eds.): Deconstructing flexicurity and developing alternative approaches, pp. 88-115. Taylor and Francis. 
Scott, J (1976), The Moral Economy of the Peasant, New Haven: Yale University Press.

Sennett, R (1998) The Corrosion of Character: The Personal Consequences of Work in the New Capitalism, New York: W.W. Norton.

Silver, BJ (2003) Forces of Labor: Workers' Movements and Globalization Since 1870. New York, Cambridge University Press.

Somavia, J (2004) Perspectives on Decent Work, ILO, Geneva.

Spencer, D (2012) 'Promoting High Quality Work: Obstacles and Opportunities, Journal of Business Ethics, 114 (3): 583-597.

Standing, G (2009) Work after globalization. Cheltenham:Edward Elgar Publishing Ltd

Standing, G (2011) The Precariat: The New Dangerous Class. London: Bloomsbury.

Streeck, W (2010) 'Taking capitalism seriously: towards an institutionalist approach to contemporary political economy', Socio-Economic Review, 9, 137-167.

Thompson, P (2003) ‘Disconnected Capitalism: or Why Employers Can’t Keep Their Side of the Bargain', Work, Employment and Society, 17(2): 359-378.

Tönnies, F (2001) Community and Society, Cambridge, Cambridge University Press.

Viebrock, E, Classen, J (2009) 'Flexicurity: a state of the art review', Working Papers on the Reconciliation of Work and Welfare in Europe RECWOWE Publication, Dissemination and Dialogue Centre, Edinburgh, available from: http://www.socialpolicy.ed.ac.uk/_data/assets/pdf_file/0013/31009/RECWP_0109_Viebrock_Clasen.pdf. 